\section{Success and succession}

\author{
Frank Larkin
}

It is a privilege to begin my term as editorin-chief of the British Journal of Ophthalmology (BJO), and with the benefit of a number of significant improvements made to the journal over the past seven years by outgoing editors-in-chief, Keith Barton, James Chodosh and Jost Jonas. Their stewardship has been successful by every measure. My responsibility for the next years is to further expand the quality and standing of BJO. In this I will not be alone.

\section{MY THANKS IN ANTICIPATION}

As a specialist in the anterior segment of the eye for some years, it has been difficult to keep abreast of developments in other subspecialties, so I am looking forward to reading manuscripts from ophthalmology more widely. This underscores my reliance on new deputy editors Mingguang $\mathrm{He}$ and Ludwig Heindl, and the BJO editorial board. They will be sharing much of the work of editing the journal, and I am sure that our authors and readers will appreciate their assistance as much as I do. My thanks to those who have offered to continue serving on the editorial board, and I welcome new recruits. Others have graciously offered to retire from the board to allow new members to join. If the first reason any peer-reviewed journal gains status is the quality of its submitted manuscripts, the second is the quality of its

Correspondence to Dr Frank Larkin, Moorfields, London, UK; f.larkin@ucl.ac.uk reviewers. Thank you if you have served as a reviewer for the BJO; I hope that we will be able to count on your expertise in future. As the journal currently receives about 230 manuscripts per month, our commitment to providing an expeditious and the fairest possible review of all manuscripts is no small task.

\section{OUR RESPONSIBILITY TO READERS}

If the aforementioned comments indicate our responsibilities to authors, what are our responsibilities to readers? Contemporary clinicians are faced with huge numbers of articles and opinion pieces in journals, throw-away specialist magazines and equivalent online communications. Little of this is peer-reviewed; much is not worth reading on account of bias or undeclared commercial interests. To make matters more difficult, regulation of devices is much less rigorous than medicines; more than most specialists, ophthalmologists are continually faced with new implants, intraocular devices and lasers, which might be discovered to be injurious some time after initial use in patients. There is a fine balance between innovation and harm, between inventions that introduce a step-change in eye disease management and those which are quickly abandoned as worthless or worse. The $B J O$ will be at the forefront of journals in putting a high value on thorough clinical evaluation, on independent analysis and helping readers evaluate innovation.
OPHTHALMOLOGY'S WONDERFUL HERITAGE AND PROMISING FUTURE

It is not the most auspicious time to commence a term as an editor. Due to the coronavirus pandemic, there has been a year-long moratorium on conferences and the face-to-face meetings with ophthalmologists around the world with whom it would have been so helpful to discuss new initiatives for the BJO. However, the journal's first edition was published in 1917 during a world war and a time when communication was almost incomparably more difficult. Ophthalmology has a wonderful heritage. Those researchers now imaging the retina or visual field or teaching machines to analyse these might look with interest at the BJO issue of April 1921. Most of the contents of that issue 100 years ago were articles on ophthalmoscopy and examining the visual fields. Whatever about the past, our future seems full of promise. Ophthalmology is now in the front rank in translational medicine in many domains: gene and cell therapies, imaging and image analysis to name a few. I look forward with great anticipation to the advances that will occur during my editorial term.

Provenance and peer review Commissioned; internally peer reviewed.

(C) Author(s) (or their employer(s)) 2021. No commercial re-use. See rights and permissions. Published by BMJ.

(D) Check for updates

To cite Larkin F. Br J Ophthalmol 2021;105:445. Published Online First 17 February 2021

Br J Ophthalmol 2021;105:445.

doi:10.1136/bjophthalmol-2021-319027 